\title{
Changing people demands to policies: The roles of elected representatives at Kubang Pasu District, Malaysia
}

\author{
Malike Brahim \\ School of Government, University of Utara Malaysia, Kedah, \\ Malaysia \\ malike@uum.edu.my
}

Musliza Mohamad

Department of Commerce, Polytechnic of Sultan Abdul Halim

Mu'adzam Shah, Kedah, Malaysia

mamabab999@gmail.com

Mohamad Zaki Ahmad

School of Tourism, Hospitality and Event Management, University of

Utara Malaysia, Kedah, Malaysia

raki.ahmad@uum.edu.my

Abstract. People have various demands to the government. In the plural society in Malaysia, the demands are different for different groups striving to obtain access to finance, better healthcare, housing, subsidies, security and other human necessities. These and other demands are channeled to the government through elected representatives. However, not all demands will be fulfilled, they need to be evaluated and prioritized by the government before changes in public policies are made. Interviews were conducted with the elected representatives to scrutinize the problems faced by people in their constituencies. Also, questionnaires have been distributed to examine problems and issues at the grass root. The research findings indicate that people's demands are divided into eight priorities such as education, housing, agriculture, animal husbandry, safety, facilities, religious issues and household issues. Basing on the political system theory, the demands are processed as input by the government and output is produced in the form of aids, projects, programs and plans arranged by the federal and various other agencies. Once policies are implemented, people give their feedback as the outcome from the policies' implementation.

Keywords: demands, elected representatives, Malaysian societies, policy implementations, public policy.

JEL Classification: A13, D31, D78. 


\section{INTRODUCTION}

The well-being of communities in the plural society in Malaysia puts forward different demands to the government. These demands stem from various economic and demographic factors. What do people need the most? Food, water, healthcare, housing, education and security are among the main life necessities. Some people need food, but may want rice, milk, and meat, but to others food means fruits, vegetables, and wheat cookies. Personal needs become demands when they are directed at specific goods that might satisfy their needs.

In today's scenario, people in Malaysia are facing several problems with fulfilment of their needs. Some are confused and are unable to handle their personal problems as such. To get assistance, they meet the elected representatives (ERs). This is one of routine daily duties of political personnel in serving people. The ERs have certain approaches in handling the constituents' problems. Although some demands from the people will be channelled to the federal or state governments, in many instances the ERs need to spend their own money to help people.

This article discusses the findings of the research conducted in Kubang Pasu District, Kedah, examining the priority demands, particularly those of the poor group. Generally, peoples' demands are different depending on their socioeconomic activities. The government introduces various policies to meet these needs. Once these policies are implemented, people provide their feedback on whether they are satisfied or otherwise. Not all policies will make people happy, whereas some will create additional hardships, distress and increase the cost of living. Therefore, feedback from people is most important to the government while evaluating the performance and achievements from each implemented policy.

\section{PEOPLE DEMANDS FROM THE PERSPECTIVES OF POLITICAL SYSTEM THEORY}

How the ERs changed the people demands through policies? These issues will be emphasized from the public policy perspective through the political system theory. This theory as indicated in Figure 1 described the relationship between the ERs and people that will create the demands and supports. The demands and supports by people is assumed as input and it needs to be processed by the government (political system) as output (Brahim, 2008). Demands from the people are categorized by priority as indicated in Table 2. The people expect the ERs to fulfil their problems before it is submitted to the government. Instead, the ERs can make their own decisions to help the people. Not all demands will be fulfilled because the government needs to evaluate its priority first.

What is public policy? Public policy is a combination of basic decisions, commitments, and actions made by the government. The decisions can be in term of vision adoption for the citizens relating to a specific issue for example, prohibiting crimes. According to Fowler (2009), policy-making requires political wisdom, diplomacy, and prudence in delivering diverse community interests together around a shared purpose. However, policy making is not an easy process. The policymakers need to consider and weigh by balancing public values. Regarding this matter, Fowler (2009) mentioned that since our government is a representative democracy, an effective policy-making process ensures that all relevant viewpoints are heard and that the rights of individuals are protected.

However, the policy-making is often undervalued and misunderstood (Municipal Research \& Services Center of Washington, February 1999). Therefore, policymakers need to assess the priority of each demand of the people before it is transformed into policies. The policies created by the government affect everyone in the community one way or another. To fulfil the peoples' demands and solve their problems, public policy determines what services will be provided to the residents, what kinds of development will occur in 
the community. All of these determine what the community's future will be. Policies are created to guide decision making.

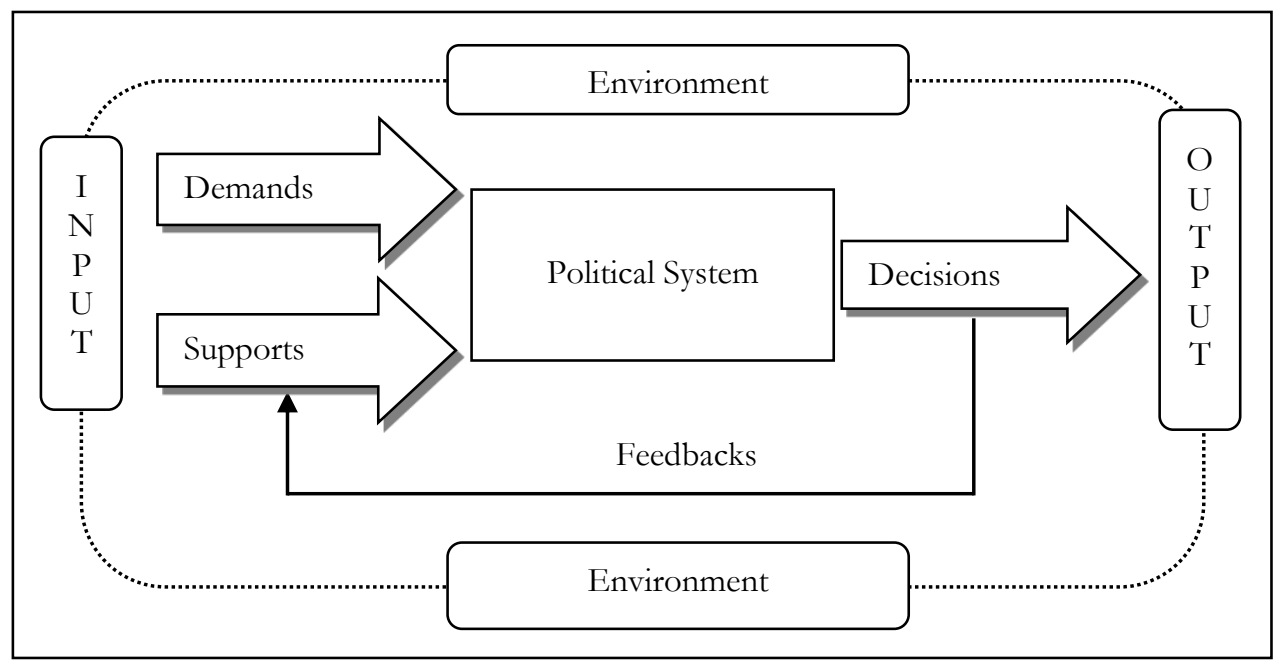

Figure 1. Political system theory

Sources: Modified from Dye, 2011; and Lester \& Stewart, 2000

The policy process is a sequence of events that occurs when a political system considers different approaches to public problems, adopts one of them, implement and evaluates the outcome. Therefore, Firestone (1989) explained that political scientists often use game metaphors in describing the policy-making process. Like a game, this process has rules and player and appears very complex that was later played in many areas and involves the use of power. And like a game, it is culminated with winners and losers. For Bryson and Crosby (1992), this process is driven by policy issues as discussed in this article as efforts to examine the approaches taken by the ERs to fulfil the demands and answering questions from the people.

\section{RESEARCH BACKGROUND AND METHODOLOGY}

This research was conducted to investigate the demands from people to the ERs in the Kubang Pasu District. The demands assumed inputs with regard to the political system theory. In this theory, the demands from people are an input that needs to be processed by the political system (government) before being changed into outputs as results of projects, programmes and plans that will directly give an impact as outcomes to peoples' lives and influence their satisfaction. However, not all demands were fulfilled because the government needs to evaluate its priorities. Therefore, the purposes of this study are:

a) To examine the diversity of demands as inputs from people to the ERs before being channelled to the government;

b) To identify the actions taken by the ERs or government as outputs to fulfil the demands from people before being formulated as policies; and

c) To analyse the demands from people based on the priorities on how the government solves issues that arise within the societies.

This research was conducted using personal interviews or face-to-face interview with the ERs in Kubang Pasu District. For Neuman (2006), face-to-face interviews have the highest response rate and permit the longest questionnaires. Therefore, this research exercised the interview in gathering direct information from the ERs. The structured questions are created for the interview to investigate what kind of demands that are always requested from people to the ERs. As information, Kubang Pasu District has 
four constituencies for Kedah State Assembly such as Bukit Kayu Hitam, Jitra, Kota Siputeh and Air Hitam. All the constituencies are represented by the ERs from the National Front party which is Ahmad Zaini Japar for the Bukit Kayu Hitam, Aminuddin Omar for the Jitra seat, Abu Hassan Sharif for the Kota Siputeh seat and Mukhriz Mahathir for the Air Hitam seat. All the ERs were interviewed except Mukhriz.

This research also used a survey by questionnaire. The questionnaires were used to solicit the views of the people who live in the Kubang Pasu District. The feedback from the questionnaires would counter and consolidate the information from the interviews. A hundred questionnaires were distributed because this is a small-scale study and the selection of the respondents was based randomly selected. The questionnaire was divided into nine sections involving household's aids; education; infrastructure and utility; agriculture and farming; socio-economy and business; religious and worship; family and inheritance; and health and safety in identifying the people's priority.

To measure the feedback from respondents, the questionnaire using the four-point Likert scale that ranges from one to four, as $1=$ Never, $2=$ Seldom, $3=$ Sometimes, and $4=$ Often. After reviewing the feedback returned, only 69 questionnaires were qualified for analysis. All answers collected by questionnaires were analysed based on simple descriptive statistics such as frequency, percentage, and mean as indicated in each table below. Although the research findings did not represent the whole citizens of Kubang Pasu District, the respondents' feedback portrayed the types of demands from the people. Hence it fulfilled the aims of this study to determine the priority of demands from people to the ERs.

\section{RESEARCH FINDING AND DISCUSSION: PRIORITY DEMANDS FROM PEOPLE}

From 69 respondents, only 66.7 percent of them have monthly income of more than Malaysia Ringgit (MYR) 1,500 as indicated in Table 1. Majority of the respondents work in the public sector. Few of the respondents have incomes below that rate. Some of them do not have permanent income and some earned below than MYR500. These findings showed that majority of the respondents were categorized as low or middle incomes class. Therefore, if the cost of living and price of goods increased, this group could face many difficulties and will find it as struggles to survive. If they have no choice in handling their problems, the best alternative is to meet their leaders and ER.

Based on this situations, majority of the respondents receives the One Malaysia People's Aid (BR1M). ${ }^{1}$ The BR1M program was first introduced by Prime Minister Mohd Najib Razak in the year 2012 as part of the government's effort to ease the burden and help the lower income group by cushioning the high cost of living in Malaysia. BR1M is also part of the Government's Economic Transformation Program (ETP) to turn Malaysia into a high-income nation. In the first year it was introduced, the government gave MYR500 to households that were qualified and in the year 2016 it was increased to MYR900. More than MYR5 billion had been allocated for the year 2016 alone while the government had estimated that the BR1M pay-outs will be accumulated to MYR13 billion from 2012 to 2015. There is no denying that the 7 million Malaysians eligible for BR1M will be waiting eagerly for their cash handouts.

\footnotetext{
${ }^{1}$ BR1M program which stands for "Bantuan Rakyat 1 Malaysia" is started on 2012 as part the government effort to assist the lowincome earners in Malaysia. The government will give a one-time MYR500 BR1M assistant to eligible people as part of government effort to reduce the cost of living faced by the people. Mohd Najib has affirmed that BR1M program will be continued for years as Malaysia's revenue continues to increase and has announced that BRIM program will be continued on recent Budget 2018 presentation. As for BR1M 2018, the lead family member shall receive MYR1,200 for a family with household income below MYR3,000. Family with household income between MYR3,000 and MYR4,000 shall receive MYR900 aid. An MYR450 aid will be given to single individuals that are over 21 years old.
} 
Monthly Incomes

\begin{tabular}{|l|r|r|}
\hline \multicolumn{1}{|c|}{ Rate of Incomes } & Frequency & Percentage \\
\hline MYR1,500 above & 46 & 66.7 \\
\hline MYR1,001 to MYR1,500 & 5 & 7.2 \\
\hline MYR500 to MYR1,000 & 11 & 15.9 \\
\hline Below MYR500 & 1 & 1.4 \\
\hline No Permanent Incomes & 6 & 8.7 \\
\hline \multicolumn{1}{|c|}{ Total } & $\mathbf{6 9}$ & $\mathbf{1 0 0 . 0}$ \\
\hline
\end{tabular}

Source: Brahim, Ahmad, Sakdan \& Ismail, 2016

The survey result in Table 2 indicated the priorities from highest to lowest demands from people to the ERs. These eight priorities surrounding the issues on religious and house of worship was the most asked towards the elected representatives based on the mean values (1.70) and followed by the issues about the safety and health (mean 1.58). The lowest demands were for the need of socio-economic and business (mean 1.16). The details on each demand on the aspects that people need in the societies will be discussed later. The interview results also indicated that the ERs have methods in solving the people problems depending on their capabilities and support by other government agencies.

Table 2

The priority demands from people

\begin{tabular}{|l|c|c|c|c|c|}
\hline \multicolumn{1}{|c|}{ Assistance Needed (N=69) } & Mean & Median & $\begin{array}{c}\text { Standard } \\
\text { Deviation }\end{array}$ & Minimum & Maximum \\
\hline Religious and houses worship & 1.7058 & 1.3000 & .92798 & 1.00 & 5.20 \\
\hline Safety and health & 1.5899 & 1.3000 & .78967 & 1.00 & 4.40 \\
\hline Infrastructure and utilities & 1.4652 & 1.1000 & .71039 & 1.00 & 4.00 \\
\hline Agriculture and farming & 1.3406 & 1.0000 & .66229 & 1.00 & 3.90 \\
\hline Household & 1.3174 & 1.0000 & .56930 & 1.00 & 3.20 \\
\hline Education & 1.2812 & 1.0000 & .41205 & 1.00 & 2.70 \\
\hline Family and legal issues & 1.2609 & 1.0000 & .47192 & 1.00 & 3.00 \\
\hline Socio-economic and business & 1.1638 & 1.0000 & .36339 & 1.00 & 2.90 \\
\hline
\end{tabular}

Source: Brahim, Ahmad, Sakdan \& Ismail, 2016

There are different demands from people to the government. To fulfil the people demands, the Malaysian government has provided several programs to help individuals who have exhausted or may soon exhaust their living expenses. For example, an unemployed individual may be eligible for assistance to meet basic needs as well as other services such as health care, employment and training assistance, finance, and many others. However, the priorities to help the people are depending on the government's financial capabilities and supported by the public agencies, private sector, and NGOs. The research has found seven overarching priority demands into the religious and worship as indicated in Table 3 which included a religious festival, clean the house of worship and graveyard enlargement or to build new houses of worship, the ceremony for the Quran recitation and pilgrimage to Mecca. For example, people have a need related to the religious and house of worship that indicate 20.6 percent of respondents that often asked the ERs to support their application to organize religious ceremony. These issues followed by the request for assistance to clean the houses of worship (14.7 percent) and clean graveyard area (10.3 percent). 
Religious and Houses Worship Needs

\begin{tabular}{|l|c|c|c|c|c|}
\hline \multicolumn{1}{|c|}{ Types of Need } & Mean & Never & Seldom & Sometimes & Often \\
\hline Religious festival & 2.06 & $57.4 \%$ & $8.8 \%$ & $13.2 \%$ & $20.6 \%$ \\
\hline Clean houses of worship & 1.96 & $54.4 \%$ & $14.7 \%$ & $16.2 \%$ & $14.7 \%$ \\
\hline Clean the grave & 1.81 & $58.8 \%$ & $16.2 \%$ & $14.7 \%$ & $10.3 \%$ \\
\hline Enlarge houses of worship & 1.80 & $55.9 \%$ & $25.0 \%$ & $7.4 \%$ & $11.7 \%$ \\
\hline Build the houses of worship & 1.74 & $61.8 \%$ & $17.6 \%$ & $10.3 \%$ & $10.3 \%$ \\
\hline Ceremony for Quran recital & 1.72 & $63.2 \%$ & $14.7 \%$ & $11.8 \%$ & $10.3 \%$ \\
\hline Pilgrimage to Mecca & 1.30 & $85.3 \%$ & $5.9 \%$ & $2.9 \%$ & $5.9 \%$ \\
\hline
\end{tabular}

Note: 4=Often; $3=$ Sometimes; $2=$ Seldom; and 1=Never Source: Brahim, Ahmad, Sakdan \& Ismail, 2016

The Kedah State Assemblyman's have their own styles and approaches to fulfill the people demands regarding the religious and worship section. Ahmad Zaini said he always help the people in Bukit Kayu Hitam constituency using his own money or allocation provided by the government. ${ }^{2}$ For some cases, Ahmad Zaini asked the government agencies like Welfare Department, District Office to take necessary actions. For example, the Muslims people demand to build a new mosque or enhance the old mosques using funds from the Kedah States Islamic Council. He helped the people to build mosque through the state fund and the Prime Minister's Department grants, private companies and public donations. Whereas to build up the Hindu temples, the government used a special fund from gambling tax that is managed by the Finance Ministry for cost not exceeding MYR20,000.

Meanwhile, Abu Hassan informed that there is a total of 36 mosques in the Jerlun constituency under the state government supervision. ${ }^{3}$ Most demands from the people were to replace the carpet, repair the roof, upgrade the audio systems and many others. Aminuddin too mentioned a similar situation where the people met him for some assistance. ${ }^{4}$ During the hajj season, the people always ask the ERs to acquire early turn because their names were not listed to go to Makkah. Therefore, the ERs brought their cases to the Malaysian Hajj Pilgrims Fund Board to request for an early turn. For those who were selected, the ERs gave some pocket money to buy some necessities for hajj and small amounts of pocket money during hajj. On the other hand, the non-Muslim houses of worships were funded depending on their financial ability.

In facts, the religious and worship also is an important issue in such countries. For example, they try to optimize the roles of the mosque for other functions. The mosque or other worship can be the best platform to promote the prosperity and solidarity between different ethnics in a country and also generate good communication if they a problem to solve. At the same, for Muslim communities, the role of mosques is not just for performing the prayer, but to promote the Islam's building design and architecture. Therefore, this research finding is significant with other research findings and articles. For example, Abdul Ruff (June $27,2016)$ has some views about the importance of mosques for imparting proper Islamic worship and knowledge. He said, “A mosque is generally a very symbolic place for a Muslim, being a bumble way for Muslims to recreate pure divine presence on earth. The primary purpose of the mosque is to serve as a place where Muslims can come together for

\footnotetext{
2 Malike Brahim, (2014, July 31). Personal interview with Ahmad Zaini Japar the Bukit Kayu Hitam State Assemblyman of Kedah.

${ }^{3}$ Malike Brahim, (2014, August 20). Personal interview with Abu Hassan Sharif the Kota Siputeh State Assemblyman of Kedah.

${ }^{4}$ Malike Brahim, (2014, June 11). Personal interview with Aminuddin Omar the Jitra State Assemblyman of Kedah.
} 
prayer. Nevertheless, mosques are known around the world nowadays for their Islamic architecture but most importantly for its general vitality to the Muslim Ummah (community)". This statement describes the importance of religious and worship for the community and not just for Muslims. He added, the mosque brings the community together as it acts as a social center, a community center, an educational center and many other functions as it held many events that welcomed both old and new members of the mosque.

According to Alean Al-Krenawi (2016), the mosque has a significant role in the Muslim community not solely as place for prayers but provides educational, political welfare and conflict resolution services in times of dispute between groups, families, couples and individuals. Therefore, he said social workers should expand their knowledge of the mosque and the Imam (head of mosque) and acknowledge the vital role they play in the Muslim community. His belief that the mosque and Imam can work together with the social workers and supply the cultural and social knowledge that is required for proper assistance to be given. For Al-Krenawi (2016), this approach will help bridge the gap between local-religions and Western models of intervention. The issues Al-Krenawi discussed is significant with this research finding to identify the people needs regarding the religious and worship needs.

On the issues of safety and health, currently the people are more aware of the disease, hygiene, crime, public safety and others as shown in Table 4. Frequently, they have requested to clean the village or residential areas (mean 1.90) which is 10.3 percent of the respondents. Other demands were also about safety and hygiene campaign (mean 1.78), drainage and sewage channel maintenance (mean 1.78) and disease control of infections (mean 1.72). This is followed by the need to control criminal activities at their residential area. The people suggested the ERs to form voluntary patrol units (VPU) (mean 1.62), neighborhood watch (mean 1.55) and voluntary fire body (mean 1.23). According to Ahmad Zaini, the voluntary patrol units were established based on the community demands by receiving funds from the Department of National Unity and Integration. Meanwhile the safety and health programs were under the responsibility of agencies such as the Kubang Pasu District Council (KPDC), and the Health Department for activities such as drainage maintenance and street lighting in urban and rural areas.

Table 4

Health and Safety Needs

\begin{tabular}{|l|c|c|c|c|c|}
\hline \multicolumn{1}{|c|}{ Types of Need } & Mean & Never & Seldom & Sometimes & Often \\
\hline Clean the village/residential area & 1.90 & $52.9 \%$ & $20.6 \%$ & $16.2 \%$ & $10.3 \%$ \\
\hline Safety and hygiene campaigns & 1.78 & $57.4 \%$ & $22.1 \%$ & $10.3 \%$ & $10.3 \%$ \\
\hline Drains/sewage maintenance & 1.78 & $60.3 \%$ & $17.6 \%$ & $11.8 \%$ & $10.3 \%$ \\
\hline Control of infectious diseases & 1.72 & $63.2 \%$ & $14.7 \%$ & $13.2 \%$ & $8.9 \%$ \\
\hline Voluntary patrol unit & 1.62 & $69.1 \%$ & $11.8 \%$ & $10.3 \%$ & $8.9 \%$ \\
\hline Neighborhood watch & 1.55 & $73.5 \%$ & $10.3 \%$ & $7.4 \%$ & $8.9 \%$ \\
\hline Road lighting/traffic light & 1.43 & $73.5 \%$ & $16.2 \%$ & $8.8 \%$ & $1.5 \%$ \\
\hline Voluntary fire body & 1.23 & $88.2 \%$ & $5.9 \%$ & $2.9 \%$ & $2.9 \%$ \\
\hline
\end{tabular}

Note: 4=Often; $3=$ Sometimes; $2=$ Seldom; and $1=$ Never

Source: Brahim, Ahmad, Sakdan \& Ismail, 2016

Abu Hassan stated that the VPU was able to reduce the rate of thefts, house breaking and entering incidents in Jerlun constituency. Meanwhile, the activities to clean the village are often held in collaboration with the Health Department to control the dengue pandemic. The government was also concerned about road safety and allocated MYR1 million to build traffic lights in Simpang Kemboja and Pekan Lintang. In the case of storm and floods in this constituency, the National Security Council and National Energy Ltd. 
have taken the initiatives in building new houses for the victims under the Baiti Jannati (welfare's house project) suggested by former Chief Minister, Mukhriz Mahathir.

In the Jitra constituency, the VPU was established for people to safeguard because the safety issues were not fully under the police responsibility but requires the cooperation of the community. In health issues, if there were any dengue fever cases, the Village Safety and Development Committee (VSDC) is directed to conduct cleaning activities in collaboration with the Health Department. As for the flooding issue, the government had spent a huge sum of money in building fortresses and flood mitigation by deepening several rivers in the Jitra constituency. Traffic lights were built at the junction in Taman Bersatu in collaboration with the Works Department to ensure road safety.

The findings as discussed above aligned is with Friedan (2013) analysis on public health as a basic task of government. However, this issue sometimes was characterized as inappropriately intrusive. The government must take serious actions to enhance the quality of the processes provided for public health. For Friedan (2013), care for the public's health includes the efforts to promote and protect individuals from being harmed by others and facilitate societal action to promote and protect health. These are the responsibilities of the government to protect individuals from preventable harm caused by other individuals or groups from unhealthy environment and so forth. Nowadays, the people were concerned and had alerted the government on the roles to prevent deterioration in the quality of food and water. This also include the effort in reducing alcohol-impaired driving and other pertinent issues (Friedan, 2016).

Instead, West and Bernstein (2017) talked about public safety as an important aspect for people. At some places or cities, the public safety is uncertain and more chaotic, dangerous and volatile. Therefore, the government needs to prevent and enhance public safety to increase the social and economic prosperity. Undoubtedly, people need security to live day-to-day and undertake business and communications. West and Bernstein suggested the government need to promote the digital technology to improve public safety, promote stronger ties between law enforcement and the community, integrate solutions such as video, data, and analytics into effective solutions, and give security officials stronger tools for outreach and coordination. They examine the ways that digital technology, mobile networks, and integrated solutions help officials in 17 cities manage public safety and law enforcement (West \& Bernstein, 2017).

Another demand from the people is the need for the infrastructure and utility as shown in Table 5. The research findings showed the most frequent assistance were to construct mini roads at the rural areas (mean 1.72), followed by drains, ditches, watercourses, and canals (mean 1.65), telephone and broadband (Wi-Fi) (mean 1.49), football field and sports court (mean 1.49) and playground (mean 1.45). The needs for construction, repairs and road upgrade were the priority for the rural communities when 10.3 percent of respondents agreed that they often brought up these issues to the ERs. Meanwhile, 13.2 percent of them also had submitted their applications for drains, trench and canal maintenance that were related to their routine activities as farmers. The purpose was to avoid flooding that would destroy their paddy plants and its production. The reasons why the people asked the ERs to bring up their voice to the government to build the dam and boundary was to prevent these disasters.

Regarding the issue, Ahmad Zaini explained that the government provided some budget through the Ministry of Rural and Regional Development to fulfill some demands from the people for infrastructure and utility development. The budget was channeled to the District Office as the agent at the grass root. Meanwhile, the Implementation Coordination Unit (ICU), the Prime Minister's Office, and the State Economic Planning Unit were responsible for ensuring that infrastructure and utilities were built according to government-approved plans and provisions. According to Abu Hassan, many requests were made including the construction of toilets at mosques and the construction of mini roads in the villages. Therefore, the application must go through the VSDC as a proper procedures before it is submitted to the government. 
Infrastructure and Utility Needs

\begin{tabular}{|l|c|c|c|c|c|}
\hline \multicolumn{1}{|c|}{ Types of Need } & Mean & Never & Seldom & Sometimes & Often \\
\hline Road & 1.72 & $64.7 \%$ & $11.8 \%$ & $13.2 \%$ & $10.3 \%$ \\
\hline Drain/trench/canal & 1.65 & $67.6 \%$ & $14.7 \%$ & $4.4 \%$ & $13.2 \%$ \\
\hline Telephone/Wi-Fi & 1.49 & $75.0 \%$ & $8.8 \%$ & $7.4 \%$ & $8.8 \%$ \\
\hline Football field/sports court & 1.49 & $76.5 \%$ & $7.4 \%$ & $8.8 \%$ & $7.4 \%$ \\
\hline Playground & 1.45 & $75.0 \%$ & $13.2 \%$ & $5.9 \%$ & $5.9 \%$ \\
\hline Bridge & 1.39 & $79.4 \%$ & $11.8 \%$ & $2.9 \%$ & $5.9 \%$ \\
\hline Dam/boundary & 1.38 & $82.4 \%$ & $5.9 \%$ & $7.4 \%$ & $4.4 \%$ \\
\hline Bus stop cottage & 1.26 & $85.3 \%$ & $8.8 \%$ & $2.9 \%$ & $2.9 \%$ \\
\hline
\end{tabular}

Note: 4=Often; $3=$ Sometimes; $2=$ Seldom; and 1=Never

Source: Brahim, Ahmad, Sakdan \& Ismail, 2016

Aminuddin explained that many applications to upgrade the roads as well as pavement, widening and repairing damaged roads were from VSDC and resident associations. Their applications were sent to the state government and MRRD for approval. In the case of blocked drainage and upgrading of roads in the housing area, the applications were sent to the KPDC for further actions. If the cost involved huge monetary expenditure, the application will be submitted to the Ministry of Urban Wellbeing, Housing and Local Government.

Regarding the finding discussed above, O'Sullivan and Sheffrin (2003) mentioned that the infrastructure was the fundamental facilities and systems serving a country, city, or other areas including the services and facilities necessary for its economy to function. They claimed the infrastructure is composed of public and private physical improvements such as roads, bridges, tunnels, water supply, sewers, electrical grids, and telecommunications. What they said complemented this research finding. Fulmer (2009) saw the infrastructure and utility needs as physical components of interrelated systems providing commodities and services essential to enable, sustain, or enhance societal living conditions. Similarly, this research finding indicated the same issue as the priority for people at the Kubang Pasu District.

Table 6 indicated the types of people needs regarding the agriculture and farming that are frequently submitted to the ERs like seeds, fertilizers, pesticides and agricultural equipment's subsidies (mean 1.64), followed by animal and pest control (mean 1.57), advisory services (mean 1.32) and others. The analysis found that the agriculture subsidies showed 13.3 percent that is often submitted to the government. This need followed by the pests and insects control which is 11.7 percent that has been submitted for assistance. Additionally, they also requested lands for agriculture, marketing or assistance in selling their agricultural and farms produce, modern equipment and participation in entrepreneurial schemes.

Ahmad Zaini explained that the people's demands were submitted to the Farmers' Organization Authority (FOA), Rubber Industry Smallholders Development Authority (RISDA) and Muda Agricultural Development Authority (MADA) for assistance. However, not all applications were approved. The failed applicants could appeal for the subsidies or assistances. Ahmad Zaini advised these agencies for proper monitoring and supervision of their respective agricultural systems to be functional and useable. At the same time, these agencies needed to ensure that the subsidies were not misused.

In this issue, Abu Hassan mentioned that in Jerlun constituency, the community was divided into farmers, fishermen, and smallholders. Therefore, the needs were different. For example, the farmers need pesticides to poison unwanted pests, but the fishermen need boats and nets. Smallholders need the ERs or government to promote and sell their product such as rubber and oil palm. Among these group members, 
majority of them were the BR1M recipients and required additional income. Thus, the government should encourage them to increase the yields of paddy, fruits and fish caught. Hence, substantial support should be given to this group in order to increase their income.

Table 6

Agriculture and Farming Needs

\begin{tabular}{|l|c|c|c|c|c|}
\hline \multicolumn{1}{|c|}{ Types of Need } & Mean & Never & Seldom & Sometimes & Often \\
\hline Agriculture subsidies & 1.64 & $73.5 \%$ & $8.8 \%$ & $4.4 \%$ & $13.3 \%$ \\
\hline Pests animal/insects control & 1.57 & $75.0 \%$ & $7.4 \%$ & $5.9 \%$ & $11.7 \%$ \\
\hline Agriculture advisory & 1.39 & $79.4 \%$ & $8.8 \%$ & $4.4 \%$ & $7.4 \%$ \\
\hline Land for agriculture & 1.32 & $86.8 \%$ & $2.9 \%$ & $5.9 \%$ & $4.4 \%$ \\
\hline Marketing/sale of produce & 1.29 & $85.3 \%$ & $5.9 \%$ & $4.4 \%$ & $4.4 \%$ \\
\hline Modern agriculture equipment & 1.29 & $82.4 \%$ & $10.3 \%$ & $2.9 \%$ & $4.4 \%$ \\
\hline Control of animal diseases & 1.28 & $83.8 \%$ & $5.9 \%$ & $8.8 \%$ & $1.5 \%$ \\
\hline Agro-entrepreneur scheme & 1.20 & $89.7 \%$ & $1.5 \%$ & $7.4 \%$ & $1.5 \%$ \\
\hline
\end{tabular}

Note: 4=Often; 3=Sometimes; $2=$ Seldom; and 1=Never

Source: Brahim, Ahmad, Sakdan \& Ismail, 2016

In the Jitra constituency, the communities were involved in banana and lime farming activities. Therefore, they always applied for new agricultural sites. According to Aminuddin, their applications were submitted to the District Agricultural Officer and FOA to be considered. Those applying for fertilizer assistance and insect pest control were referred to the Department of Agriculture for assistance. Whereas, equipment such as water pumps, ground felling machines and other machinery assistance is submitted to Kedah Regional Development Authority (KEDA). Meanwhile Aminuddin advised the people not to just rely and depend on the government for assistance but they should think outside the box if they wanted to succeed especially as an agro-entrepreneur.

This research finding matched with Muhammad Hakimi Mohd Shafiai and Mohammed Rizki Moi (2015) analysis of the farmer's problems in Malaysia. They mentioned that, even though agricultural markets in Malaysia were free retail, there were certain inflexible elements such as government subsidies and support programs in which were in direct interference from the government in the areas of market mechanism, prices and resource allocations. This can be seen through the direct participation of the Department of Agriculture in Malaysia in supporting farmers in developing agricultural land. Nevertheless, even the farmers in Malaysia received significant aids from the government, due to some unavoidable reasons they faced especially some problems in cultivating their agricultural land from financial perspectives. Therefore, based on this research finding, the farmers in Kubang Pasu District obviously needed assistance from the ERs to solve the problems.

The people also requested some household needs as indicated in Table 7. The analysis found that the demands to pay the utility bills were the highest (mean 1.67) which is 14.7 percent often submitted to the ERs for assistance. This is followed by daily living expenses needs (mean 1.59) and 13.2 percent often requested to the ERs. They also need assistance for purchasing kitchen utensils (mean 1.48) which is 7.3 percent of this demands often submitted to the ERs. Some of them also needed money to pay the tax, repairing the house, build new houses and for the supply of electricity and water to their houses. This finding showed that the people, particularly for those who have low or no permanent incomes needed more protections from the government and the ERs in ensuring they enjoyed good living conditions. 
Household Needs

\begin{tabular}{|l|c|c|c|c|c|}
\hline \multicolumn{1}{|c|}{ Types of Need } & Mean & Never & Seldom & Sometimes & Often \\
\hline Pay utility bills & 1.67 & $76.5 \%$ & $4.4 \%$ & $4.4 \%$ & $14.7 \%$ \\
\hline Daily living expenses & 1.59 & $82.4 \%$ & $1.5 \%$ & $2.9 \%$ & $13.2 \%$ \\
\hline Kitchen utensils & 1.48 & $79.4 \%$ & $4.4 \%$ & $8.8 \%$ & $7.3 \%$ \\
\hline House repairing & 1.33 & $77.9 \%$ & $13.2 \%$ & $8.8 \%$ & \\
\hline Water pipe installation & 1.29 & $82.4 \%$ & $10.3 \%$ & $5.9 \%$ & $1.5 \%$ \\
\hline Pay assessment tax & 1.28 & $91.2 \%$ & $1.5 \%$ & $2.9 \%$ & $4.4 \%$ \\
\hline Pay land tax & 1.23 & $91.2 \%$ & $2.9 \%$ & $2.9 \%$ & $3.0 \%$ \\
\hline Electrical wiring & 1.16 & $86.8 \%$ & $11.8 \%$ & $1.5 \%$ & \\
\hline Request lands for home & 1.09 & $95.6 \%$ & $1.5 \%$ & $2.9 \%$ & \\
\hline Build new home & 1.06 & $94.1 \%$ & $5.9 \%$ & & \\
\hline
\end{tabular}

Note: 4=Often; $3=$ Sometimes; $2=$ Seldom; and 1=Never

Source: Brahim, Ahmad, Sakdan \& Ismail, 2016

The ERs mentioned that they were willing to help all citizens in their constituencies regarding households' necessities. Ahmad Zaini said the people who did not have permanent jobs and volatile income often sought for help. Despite working their wages were low and the money usually used up to repay debts. When the situation became desperate they sought the assistance from the ERs especially during school opening sessions and religious celebrations. Abu Hassan mentioned many citizens requested and collected money to pay water and electricity bills, repairing motorcycles, buying bicycles and repairing houses. Aminuddin described the people usually request for money to buy children's milk and medicines. Therefore, the ERs tried to help the people as best as they could, depending on their financial capabilities. Some of these cases were preceded by the Department of Social Welfare and Kedah State Zakat Board's monthly assistance. Those needing a house applied for one from the project of the 1Malaysia Housing Program (PR1MA) 5 and the Housing Project for the Extremely Poor.

One of the demands from the people is on the education needs as indicated in Table 8. The analysis found that the need for school fees was the highest (mean 1.59) which is 12.2 percent. It is often submitted to the ERs for assistance. For books and stationeries, it is the second highest demands (mean 1.55) from the people which were 11.8 percent often requested to the ERs. However, it was rather surprising that some respondents (mean 1.03) at 1.5 seldom asked the ERs to help them pay back their study loans.

The research findings discussed above were equivalent to the Malaysian government programs that were implemented a few years ago. The former Minister of Women, Family and Community Development Shahrizat Abdul Jalil in her speech said that "Our commitment is to ensure that even though we may not be able to eradicate poverty in the country, that we pursue this reduction in a steady and sure manner. We also commit to raising the living standards of the poor and low-income households, both the rural and urban folks. In all this, we will work to ensure that no single Malaysian gets left behind as the nation progresses forward'. As an example, the Malaysian government implemented such programs as an initiative to improve the welfare of the people as well as build income earning potential to ensure sustainability in the near future. Several visible measures that allowed for rapid

\footnotetext{
5 PR1MA was established to plan, develop, construct and maintain affordable lifestyle housing for middle-income households in key urban centers. The government plans to build affordable homes in cities and towns in Malaysia. Key criteria to apply for a PR1MA are Malaysian citizens (individuals or families) with an average monthly household income between MYR2,500 and MYR7,500; at least 21 years old at time of application; and those who currently own no more than one property.
} 
effect were identified. These included welfare assistance programs, housing supports, and the 1AZAM program. 1AZAM is a specific initiative that sets out to lift low-income households out of poverty through means of employment, entrepreneurship, agricultural activities and services (Prime Minister Office, 2010).

Table 8

Education Needs

\begin{tabular}{|l|c|c|c|c|c|}
\hline \multicolumn{1}{|c|}{ Types of Need } & Mean & Never & Seldom & Sometimes & Often \\
\hline School fees & 1.59 & $79.4 \%$ & $2.9 \%$ & $4.4 \%$ & $12.2 \%$ \\
\hline Book and stationery & 1.55 & $72.1 \%$ & $13.2 \%$ & $2.9 \%$ & $11.8 \%$ \\
\hline Study fees at university & 1.51 & $77.9 \%$ & $8.8 \%$ & $4.4 \%$ & $8.9 \%$ \\
\hline Scholarship application & 1.36 & $83.8 \%$ & $5.9 \%$ & $2.9 \%$ & $7.3 \%$ \\
\hline Boarding school & 1.22 & $92.6 \%$ & & $2.9 \%$ & $4.4 \%$ \\
\hline Uniform aids & 1.16 & $86.8 \%$ & $10.3 \%$ & $2.9 \%$ & \\
\hline Study loan installment & 1.03 & $98.5 \%$ & $1.5 \%$ & & \\
\hline
\end{tabular}

Note: 4=Often; $3=$ Sometimes; $2=$ Seldom; and 1=Never

Source: Brahim, Ahmad, Sakdan \& Ismail, 2016

For Ahmad Zaini, the aid was given according to the ability of the people. For example, he has provided special allocation for those that further their study within local or overseas universities which were MYR 800 for diplomas and MYR 1,000 for degrees. In this issue, Aminuddin did the same things as Ahmad Zaini and some students were asked to apply for the educational assistance from the Kedah State Zakat Board. Both of them also advised the students that have completed their studies to pay the study loans from the National Higher Education Fund Corporation as their responsibilities.

As indicated in Table 9, there were few demands from the people about the family and legal affairs. Frequently the people needed money for their wedding day celebration (mean 1.45) which is 13.2 percent. It is sometimes submitted to the ERs and followed by marriage registration (mean 1.43), divorce process (mean 1.14) and summons or fines payment (mean 1.39), child registration (mean 1.36), violence or abuse cases (mean 1.10) and the issue of responsibility negligence of husbands or wives. There were many family issues that needed to be solved through legal processes or courts.

Table 9

Family and Legal Needs

\begin{tabular}{|l|l|c|c|c|c|}
\hline \multicolumn{1}{|c|}{ Types of Need } & Mean & Never & Seldom & Sometimes & Often \\
\hline Wedding arrangements & 1.45 & $75.0 \%$ & $8.8 \%$ & $13.2 \%$ & $3.0 \%$ \\
\hline Marriage registration & 1.43 & $76.5 \%$ & $8.8 \%$ & $11.8 \%$ & $2.9 \%$ \\
\hline Divorce arrangements & 1.14 & $92.6 \%$ & $7.4 \%$ & & \\
\hline Pay the summons/fines & 1.39 & $77.9 \%$ & $10.3 \%$ & $7.4 \%$ & $4.4 \%$ \\
\hline Child registration & 1.36 & $80.9 \%$ & $8.8 \%$ & $7.4 \%$ & $3.0 \%$ \\
\hline Households violence/abuse & 1.10 & $92.6 \%$ & $4.4 \%$ & $2.9 \%$ & \\
\hline Ignore the responsibility & 1.10 & $92.6 \%$ & $4.4 \%$ & $2.9 \%$ & \\
\hline
\end{tabular}

Note: 4=Often; $3=$ Sometimes; $2=$ Seldom; and 1=Never

Source: Brahim, Ahmad, Sakdan \& Ismail, 2016

In resolving these issues, Ahmad Zaini elaborated that he always helped the people by ensuring the fine or summons were paid and lawyers were to be available in solving the people's problems in court. Some 
of the people that sought help in handling problems to register their marriage in Thailand because they were fined by the court because the marriage were not registered in Malaysia, their children cannot be registered with the National Registration Department for birth certificate. This will affect their school registration opportunities. The same issues rose in Abu Hassan's and Aminuddin's constituency. However, the people rarely met the ERs to discuss about household violence and physical abuse. The people also met the ERs to get the advice on how to solve their problems because the husbands or wives were not responsible. They advised the people to bring their cases to proper agencies or the court.

The family and legal needs as discussed above were significant to family prosperity and safety. For example, some children from problematic families were involved in crime and deviant activities. Therefore, to save their future, some NGOs and government agencies such as the Welfare Department organized events and programs to enhance the awareness and consciousness among parents to protect and care for their children. One of the approaches was through the counseling programs. Norhayati Mohd Noor (2014) in her analysis mentioned that, in Malaysia the family counseling is needed to boost personal development and harmony of the people and community. The purpose of the family counseling is to encourage family growth, instill mental health and good communication. Norhayati's research findings showed that the children issues were the most popular in family counseling session. The children issues that were often highlighted in the sessions were school truancy, studies problem, theft, drug addiction, smoking, illegitimate pregnancies, rape, loitering, running away from home, social ills and deviant behavior. Based on these issues, the family are in need of laws to be enforced on the children to consider the broken family background as well.

The least demand from the people was on the socio-economy and commerce need as indicated in Table 10. The rise in the price of goods and cost of living has a direct impact on low income people. Hence, they often sought assistance from the ERs. The analysis showed that the ERs always helped the people to acquire assistance from the Kedah State Zakat Board (mean 1.49). This is followed by the need to attend training or workshop for entrepreneurship program (mean 1.22). Another issue was even to solve problem with loan sharks. In the socio-economic and commerce needs, Ahmad Zaini said the people always met him for financial assistance for startup capital to operate or continue their businesses. He normally gave them his personal cash if the amount needed was small.

Table 10

Socio-Economy and Commerce Needs

\begin{tabular}{|l|c|c|c|c|c|}
\hline \multicolumn{1}{|c|}{ Types of Need } & Mean & Never & Seldom & Sometimes & Often \\
\hline Zakat aids & 1.49 & $73.5 \%$ & $11.8 \%$ & $8.8 \%$ & $5.8 \%$ \\
\hline Entrepreneurship courses & 1.22 & $86.8 \%$ & $4.4 \%$ & $8.8 \%$ & \\
\hline Business capital & 1.20 & $88.2 \%$ & $4.4 \%$ & $5.9 \%$ & $1.5 \%$ \\
\hline Food processing equipment & 1.14 & $89.7 \%$ & $7.4 \%$ & $1.5 \%$ & $1.5 \%$ \\
\hline Site rental/retail premises & 1.13 & $91.2 \%$ & $4.4 \%$ & $4.4 \%$ & \\
\hline Business expansion & 1.09 & $91.2 \%$ & $8.8 \%$ & & \\
\hline Pay back the loan & 1.09 & $91.2 \%$ & $8.8 \%$ & & \\
\hline Illegal loan (loan shark) & 1.04 & $97.1 \%$ & $1.5 \%$ & $1.5 \%$ & \\
\hline
\end{tabular}

Note: 4=Often; $3=$ Sometimes; $2=$ Seldom; and 1=Never

Source: Brahim, Ahmad, Sakdan \& Ismail, 2016

Meanwhile, Abu Hassan and Aminuddin told the applicants to obtain business capital mostly from small traders. But, if they needed bigger amount, they were directed and shown the way to apply for the 
capital from agencies such as Agro Bank, SME Bank, People's Trust Council (Majlis Amanah Rakyat [MARA]), Bumiputera Entrepreneurs Retail Project Fund (PROSPER) and others. In Kedah, the government has special allocation provided by the Kedah State Zakat Board and Welfare Department for the poor to start their business to improve their lives and earn a living. The local authority such as KPDC has provided few commercial lots with low rental rates as an opportunity for the people to participate in business. However, the issue was that the people were more interested to do the business activities in the government reserve lands, roadsides and beside school compounds that may cause many problems. Therefore, the KPDC has taken actions to prevent the invasion of the prohibited areas.

Based on the discussion above, as an effort to eradicate poverty some group from poor families needed the capital and financial support from the government agency such as AIM. According to Norhaziah Nawai and Mohamed Sharif Bashir (2016), AIM is the largest Malaysian micro credit program in poverty eradication. The AIM played an important role in poverty eradication in Malaysia by helping poor families to strive in increasing their income through micro-credit facilities. The result showed that AIM relied exclusively on female participation. Through the AIM's loan, the participants generated the income based on their product in small businesses. In the long-term, AIM targeted to reduce extreme rural poverty. Hence, the study finding provided strong evidence that micro finance is indeed an effective tool for poverty eradication. They study also highlighted a number of policies implications to improve the overall AIM performance.

\section{CONCLUSION}

It is not surprising that there were different demands from the people in the plural society in Malaysia, either in a small or large amount. Unfortunately, not all demands were met by the government because they have to evaluate the cost, expertise, duration, manpower, impact and other requirements of the demands. In fact, every action taken by the government was based on their policy. At the beginning of the discussion, this article has clarified that people's demands were inputs that must be processed by the government to be converted into output (policy) (Brahim, 2008). While the people were hoping that each of their demands were met by the government that eventually resulted in benefits.

Therefore, the effectiveness of policy implementation is very important to the government and ERs who acted as mediators in solving the demands of the people. The effectiveness and efficiency of such policy were obtained through feedback from the people that were directly receiving every impact from each policy being implemented. However, the demands were fulfilled in accordance with the priorities based on the categories analyzed above. The ERs have their personal approach to solve the people's demands that can be divided into several aspects.

Firstly, immediate action must be taken to help people who are in desperate need. For example, the needs for medicines, foods and milk should be hastened for children's health. Similarly for deaths, accidents and emergencies situation, the ERs will give immediate assistance either by using their own money or the allocation from the governments. Families who were disgraced and disturbed during the period were given immediate assistance. This situation can also be seen when people were overwhelmed by catastrophes incidents such as floods, fires and storm that can cause severe damaged to residential areas. Aid was immediately needed and immediate actions must be taken by the ERs and the local government to the victims.

Secondly, the action is considered to be periodical. The government and ERs should solve every problem through a periodic approach but can still be subjective according to priority. This was because the policies introduced by the government (federal or state) were planned to be implemented as per scheduled and in stages. For example, the development of infrastructure and utilities in rural areas had actually been 
in the government calendar with special provisions. Similarly, the construction of roads, bridges, canals and so on has been in the development agenda for the state and central governments for the people's convenience.

Periodic supports were also given to certain groups such as farmers and gardeners. They were given agricultural subsidies such as fertilizers, pesticides, seeds, machinery and equipment according to the planting and revenue collection schedule. Hence, assistance they received was not throughout the year, but on schedule. For that reason, the performance of this group was closely monitored by agencies concerned with the cooperation of the ERs. This is because some of them did not engage in agricultural activities such as planting paddy but were claiming fertilizer subsidies, seeds and pesticides from the government. Such actions did not only harm the government but showed irresponsible recipients who were reselling the items to others for personal profits.

Thirdly, the role of third parties. Not all of the problems of the people can be solved by the ERs. In some cases, the ERs do not directly refer the people's problems to the government. Sometime the people needs were referred to third parties representing the government and the private sectors. This can be seen in terms of gaining capital primarily to start a business as a small and medium entrepreneur. Therefore, those who are interested in doing business activities, but face capital problems were referred to agencies such as Agro Bank, SME Bank, MARA, PROSPER and other agencies. By going through relevant agencies, the people could apply for loans to run their business and payback the loans by installments according to the schedule agreed upon.

The role of the ERs in the above matter was very important. They acted as an agent promoting national unity and integration. This has been raised by Lee (1998) that explains "all Members of Parliament have responsibilities to the nation and the people to strengthen and promote national unity". If national unity and integration can be realized, indirectly the safety can be enhanced. Now the people were increasingly aware of this need by forming volunteer parole units and neighborhood watch under the supervision of the Department of National Unity and Integration. Through the volunteer parole unit and neighborhood watch, crime rates have been reduced with the collaboration from the police, the National Anti-Drug Agency and others.

The ERs have assisted the people throughout the above approaches. However, not all the burden and problems faced by the people are under the ERs responsibilities. The cooperation of many parties such as non-government and private organizations through their social corporate responsibility programs are essential in providing solutions. Canal parties should work together to address the people's problems, so that ERs can focus on their responsibilities as representative and legislators in the parliament or the state assembly. They can prepare themselves for the parliament or state assembly session and voice up any issues that are concerning the welfare and well-being of the societies. Basically, the ERs find themselves in complicated and burdensome duties to the nation, the constituency and the political party they represent. As political figures, they needed to participate in all deliberations on the matter of national and international importance (Brahim, 2017).

\section{ACKNOWLEDGEMENT}

The authors are thankful to the internal grant of University of Utara Malaysia (SO Code: 12499) "The Study of Voter's Priority Demands to the Elected Representatives from the System Theory Perspective" (Research ID: 2811) for financial support to carry out this research. 


\section{REFERENCES}

Al-Krenawi, A. (2016). The role of the mosque and its relevance to social work. International Social Work, 59(3), 359367. doi: https://doi.org/10.1177/0020872815626997.

Brahim, M. (2017). The Roles of Elected Representatives in Political Parties: What's the Challenges?. Asian Social Science, 13(6), 55-64. doi: https://doi.org/10.5539/ass.v13n6p55.

Brahim, M. (2008). Public Policies in Malaysia: an Introduction. Kuala Lumpur: IBS Books Pt. Ltd.

Brahim, M., Ahmad, M.Z., Sakdan, M.F. \& Ismail, S. (2016). The Study of the Priority Demands from Voters to the Elected Representatives from the System Theory Perspective. University of Utara Malaysia's Grants Research Report (unpublished).

Bryson, J.M. \& Crosby, B.C. (1992). Leadership for the Common Good: Tackling Public Problems in a Shared-Power World. San Francisco: Josey-Bass.

Dye, T.R. 2011. Understanding Public Policy (13 ${ }^{\text {th }}$ Ed.). Boston: Longman.

Frieden, T.R. (2013). Government's Role in Protecting Health and Safety. The New England Journal of Medicine, 368(20), 1857-1859. doi. http://www.nejm.org/doi/pdf/10.1056/NEJMp1303819.

Firestone, W.A. (1989). Educational Policy as Ecology of Games. Educational Researcher, 18, 18-23.

Fowler, F.C. (2009). Policy Studies for Educational Leaders: an Introduction (3 ${ }^{\text {rd }}$ Ed.). Boston: Pearson.

Fulmer, J. (2009). What in the world is infrastructure. PEI Infrastructure investor, 1(4), 30-32.

Lee, L.T. (1998). As I W as Saying: Viewpoints, Thoughts, and Aspirations of-. Subang Jaya, Selangor: Pelanduk Publications. Lester, J.P. \& Stewart, J. (2000). Public Policy: an Evolutionary Approach (3 ${ }^{\text {rd }}$ Ed.). Boston: Wadsworth Thomson Learning. Noor, N. M. (2014). Family Counseling in Malaysia: Current Issues and Practices. International Education Studies, 7(13), 33-39. doi: http://dx.doi.org/10.5539/ies.v7n13p33.

Shafiai, M. H. M., \& Moi, M. R. (2015). Financial problems among farmers in Malaysia: Islamic agricultural finance as a possible solution. Asian Social Science, 11(4), 1-16. doi: http://dx.doi.org/10.5539/ass.v11n4p1.

Municipal Research \& Services Center of Washington. (February 1999). Local Government Policy Making Process. Retrieved from http://eat'bettermovemore.org/SA/policies/pdftext/LocalPolicymakingProcess.pdf.

Nawai, N. \& Bashir, M.S. (2016). Evaluation of Micro Credit Program for Poverty Alleviation: A Case of Amanah Ikbtiar Malaysia (AIM). Conference Paper.

Neuman, W.L. (2006). Social Research Methods: Qualitative and Quantitative Approaches (6 ${ }^{\text {th }}$. Ed.). Boston: Pearson.

O’Sullivan, A. \& Sheffrin, S.M. (2003). Economics: Principles in Action. New Jersey: Pearson Prentice Hall.

Prime Minister Office. (2010). Raising Living Standards of Low Income Households. Government Transform Programs. Putrajaya: PEMANDU. Retrieved from http://gtp.pemandu.gov.my/gtp/upload/999afc34-141a-4c5c-801f45701389df74.pdf.

Ruff, A. (June 27, 2016). Importance of Mosques for Imparting Proper Islamic Worship and Knowledge. Retrieved from http:// foreignpolicynews.org/...importance-mosques-imparting-proper-islamic-worship-knowledge.

West, D.M. \& Bernstein, D. (2017). Benefits and Best Practices of Safe City Innovation. Brookings: The Center for Technology Innovation. Retrieved from https://www.brookings.edu/wp-content/.../safe-city-innovation final.pdf. 